\title{
Article
}

\section{Mechanism and Site Requirements for Ethanol Oxidation on Vanadium Oxide Domains}

Beata Kilos, Alexis T. Bell, and Enrique Iglesia J. Phys. Chem. C, 2009, 113 (7), 2830-2836• Publication Date (Web): 26 January 2009

Downloaded from http://pubs.acs.org on February 20, 2009

\section{More About This Article}

Additional resources and features associated with this article are available within the HTML version:

- $\quad$ Supporting Information

- $\quad$ Access to high resolution figures

- $\quad$ Links to articles and content related to this article

- Copyright permission to reproduce figures and/or text from this article

\section{View the Full Text HTML}




\title{
Mechanism and Site Requirements for Ethanol Oxidation on Vanadium Oxide Domains
}

\author{
Beata Kilos, Alexis T. Bell,* and Enrique Iglesia* \\ Chemical Sciences Division, Lawrence Berkeley National Laboratory, and Department of Chemical \\ Engineering, University of California, Berkeley, California 94720-1462
}

Received: September 2, 2008; Revised Manuscript Received: November 24, 2008

\begin{abstract}
The mechanism and structural requirements for ethanol oxidation to acetaldehyde were examined on $\mathrm{VO}_{x}$ domains supported on $\gamma-\mathrm{Al}_{2} \mathrm{O}_{3}$ at surface densities of 1.7-11.8 $\mathrm{VO}_{x} / \mathrm{nm}^{2}$. Raman and UV-visible spectra showed that $\mathrm{VO}_{x}$ species evolve from monovanadate to polyvanadate structures with increasing surface density with only traces of crystalline $\mathrm{V}_{2} \mathrm{O}_{5}$. Oxidative dehydrogenation $(\mathrm{ODH})$ of ethanol to acetaldehyde occurs at low temperatures $(473-523 \mathrm{~K})$ with high primary selectivities of $\mathrm{CH}_{3} \mathrm{CHO}(\sim 80 \%)$ on a catalyst with one theoretical polyvanadate monolayer. ODH turnover rates (per $\mathrm{V}$-atom) increased with increasing $\mathrm{VO}_{x}$ surface density for surface densities up to $7.2 \mathrm{~V} / \mathrm{nm}^{2}$, indicating that polyvanadate domain surfaces are more reactive than monovanadate structures. Similar trends were evident for alkane ODH reactions that also involve kinetically relevant $\mathrm{H}$-abstraction steps within reduction-oxidation catalytic sequences. Turnover rates ultimately decreased at higher surface densities because of the incipient formation of three-dimensional structures. $\mathrm{VO}_{x}$ domains of intermediate size therefore provide a compromise between site reactivity and accessibility during ethanol $\mathrm{ODH}$. The effects of $\mathrm{O}_{2}$ and $\mathrm{C}_{2} \mathrm{H}_{5} \mathrm{OH}$ pressures on ethanol $\mathrm{ODH}$ rates and the kinetic isotope effects for $\mathrm{C}_{2} \mathrm{H}_{5} \mathrm{OD}$ and $\mathrm{C}_{2} \mathrm{D}_{5} \mathrm{OD}$ confirmed the kinetic relevance of $\mathrm{H}$-abstraction from ethoxide species formed in quasiequilibrated ethanol dissociation steps; taken together with in situ infrared spectra, these data also show that ethoxide species are present at near saturation coverages on fully oxidized $\mathrm{VO}_{x}$ domains that undergo reduction-oxidation cycles during each ethanol oxidation turnover.
\end{abstract}

\section{Introduction}

Supported vanadium oxide is active for a wide range of reactions, including partial oxidation of $o$-xylene to phthalic anhydride, ${ }^{1}$ oxidative dehydrogenation of light alkanes to alkenes, ${ }^{2-5}$ oxidation of methanol to formaldehyde ${ }^{6}$ and of methane to formaldehyde, ${ }^{7}$ ammoxidation of aromatic compounds, ${ }^{8}$ and selective $\mathrm{NO}_{x}$ reduction. ${ }^{9}$ There have been a number of studies, as well, on the activity of supported vanadia for the oxidative dehydrogenation (ODH) of ethanol to acetaldehyde $^{10-19}$ or acetic acid. ${ }^{20}$ These studies have shown that the catalyst activity depends on the nature of the support, and that higher rates are achieved with supports such as $\mathrm{Al}_{2} \mathrm{O}_{3}$, $\mathrm{Al}_{2} \mathrm{O}_{3}-\mathrm{ZrO}_{2}, \mathrm{TiO}_{2}, \mathrm{TiO}_{2} / \mathrm{SiO}_{2}$, and $\mathrm{ZrO}_{2}-\mathrm{SiO}_{2}$ than with $\mathrm{SiO}_{2}$. In all cases, acetaldehyde is observed as the primary product, and acetic acid is observed at higher temperatures and conversions. Small amounts of ethene have also been observed with acidic supports. The dependence of catalyst activity on the surface coverage of vanadia and the reaction kinetics have been reported for vanadium supported on silica. ${ }^{21}$ The present study was undertaken to understand the effects of vanadia surface density on the rate of oxidative dehydrogenation of ethanol on alumina-supported vanadia. The specific rate and selectivity as a function of reactant pressure and vanadia surface density of this reaction were also examined to elucidate the mechanism by which this reaction proceeds.

\section{Experimental Methods}

2.1. Catalyst Preparation. Fumed $\gamma-\mathrm{Al}_{2} \mathrm{O}_{3}$ (Degussa $\mathrm{AG}$; BET surface area $119 \mathrm{~m}^{2} \mathrm{~g}^{-1}$ ) was contacted with deionized water and dried at $383 \mathrm{~K}$ for $72 \mathrm{~h}$. The dried material was then

* Authors to whom correspondence should be addressed. E-mail bell@berkeley.edu; iglesia@berkeley.edu. heated in dry air (Praxair, zero grade) flowing at $0.83 \mathrm{~cm}^{3} \mathrm{~s}^{-1}$ $\mathrm{g}^{-1}$. The temperature was raised at $0.167 \mathrm{~K} \mathrm{~s}^{-1}$ to $823 \mathrm{~K}$ and then held at $823 \mathrm{~K}$ for $5 \mathrm{~h}$. The treated alumina was stored in glass container to keep it away from ambient moisture. $\mathrm{VO}_{x} /$ $\mathrm{Al}_{2} \mathrm{O}_{3}$ catalysts with surface densities of 1.7 to $11.8 \mathrm{~V} / \mathrm{nm}^{2}$ were prepared by incipient wetness impregnation of the treated $\gamma-\mathrm{Al}_{2} \mathrm{O}_{3}$ at ambient temperature with 2-propanol (Sigma-Aldrich, 99.9\%) solutions of vanadium(V) oxytriisopropoxide (SigmaAldrich, 99\%). This V-precursor was used because it leads to a higher dispersion of oxide domains than that obtained from ammonium metavanadate. ${ }^{22}$ The catalyst synthesis was performed inside a glovebox flushed continuously with dry $\mathrm{N}_{2}$ to avoid hydrolysis of alkoxide precursors by ambient moisture. After impregnation, the samples were dried overnight at ambient temperature and transferred into a quartz reactor sealed with stopcocks. The impregnated samples were then treated at 393 $\mathrm{K}$ in flowing He (Praxair, 99.999\%, $0.33 \mathrm{~cm}^{3} \mathrm{~s}^{-1} \mathrm{~g}^{-1}$ ) for $1 \mathrm{~h}$ and at $573 \mathrm{~K}$ for $1 \mathrm{~h}$; then, dry air (Praxair, zero grade, 0.33 $\mathrm{cm}^{3} \mathrm{~s}^{-1} \mathrm{~g}^{-1}$ ) was introduced, and samples were held at $573 \mathrm{~K}$ for $1 \mathrm{~h}$, and at $773 \mathrm{~K}$ for $2 \mathrm{~h}$. The samples were pressed into wafers and crushed and sieved to retain aggregates with 250-500 $\mu \mathrm{m}$ diameter. The nominal V surface density for each sample is reported as $\mathrm{V} / \mathrm{nm}^{2}$, based on the $\mathrm{V}$ content and the BET surface area of each sample (Table 1).

2.2. Catalyst Characterization. Surface areas of $\mathrm{Al}_{2} \mathrm{O}_{3}$ and $\mathrm{VO}_{x} / \mathrm{Al}_{2} \mathrm{O}_{3}$ were measured by multipoint $\mathrm{N}_{2}$ (Airgas, 99.999\%) physisorption at $77.4 \mathrm{~K}$ using a Quantasorb 6 apparatus (Quantachrome Corp.). Before $\mathrm{N}_{2}$ adsorption, the samples $(0.2 \mathrm{~g})$ were degassed in dynamic vacuum $(0.1 \mathrm{~Pa})$ at $473 \mathrm{~K}$ for at least $3 \mathrm{~h}$. The surface areas for all samples are listed in Table 1.

Diffuse reflectance UV-visible spectra were measured with a Varian-Cary 6000i spectrophotometer equipped with a Harrick 
TABLE 1: BET Surface Area and $\mathrm{VO}_{x}$ Surface Density for $\mathrm{VO}_{x} / \mathrm{Al}_{2} \mathrm{O}_{3}$ Catalysts

\begin{tabular}{ccccr}
\hline catalyst & $\begin{array}{c}\mathrm{V}_{2} \mathrm{O}_{5} \\
\text { loading }(\text { wt. } \%)\end{array}$ & $\begin{array}{c}\text { surface area, } \\
\left(\mathrm{m}^{2} / \mathrm{g} \text { cat. }\right)\end{array}$ & $\begin{array}{c}\text { surface area, } \\
\left(\mathrm{m}^{2} / \mathrm{g} \mathrm{Al}_{2} \mathrm{O}_{3}\right)\end{array}$ & $\begin{array}{c}\mathrm{VO}_{x} \text { surface density, } \\
\left(\mathrm{V} / \mathrm{nm}^{2}\right)\end{array}$ \\
\hline $3 \mathrm{VO}_{x} / \mathrm{Al}_{2} \mathrm{O}_{3}$ & 3 & 115 & 119 & 1.7 \\
$5 \mathrm{VO}_{x} / \mathrm{Al}_{2} \mathrm{O}_{3}$ & 5 & 112 & 118 & 2.9 \\
$7 \mathrm{VO}_{x} / \mathrm{Al}_{2} \mathrm{O}_{3}$ & 7 & 113 & 121 & 4.1 \\
$10.5 \mathrm{VO}_{x} / \mathrm{Al}_{2} \mathrm{O}_{3}$ & 10.5 & 96 & 108 & 7.2 \\
$15 \mathrm{VO}_{x} / \mathrm{Al}_{2} \mathrm{O}_{3}$ & 15 & 84 & 99 & 11.8
\end{tabular}

Scientific diffuse reflectance attachment (DRP) and a reaction chamber (DRA-2CR). Samples were dehydrated in a flow of $16.7 \mathrm{~cm}^{3} \mathrm{~s}^{-1} \mathrm{~g}^{-1}, 10 \% \mathrm{O}_{2}$ in $\mathrm{He}$ (Praxair, $99.99 \%$ ) at $673 \mathrm{~K}$ for $1 \mathrm{~h}$, before measuring spectra. All spectra were acquired at ambient temperature with $1-5 \mathrm{eV}$ incident light. The Kubelka-Munk function $\left(F\left(R_{\infty}\right)\right)$ was used to convert reflectance data into absorption spectra, based on the reference reflectance of $\mathrm{MgO}^{23}$ Absorption edge energies were calculated from the intercept with the abscissa of a linear regression of $\left[\left(F\left(R_{\infty}\right)\right) h v\right]^{1 / 2}$ data as a function of $h v{ }^{23}$

Raman spectra were measured with a Hololab Series 5000 research spectrometer (Kaiser Optical) equipped with a Nd YAG laser frequency doubled to $532 \mathrm{~nm}$. The laser was operated at $75 \mathrm{~mW}$, and the scattered light was detected using a Princeton Instruments TEA/CCD detector operated at $233 \mathrm{~K}$. The Raman cell contained a rotating sample holder that eliminated potential structural changes induced by excessive laser heating of samples. Catalyst samples were pressed into wafers $(0.9 \mathrm{~cm}$ diameter, $\sim 50 \mathrm{mg} \mathrm{cm}^{-2}$ thickness) at $100 \mathrm{MPa}$. Spectra were measured at ambient temperatures using wafers treated in flowing dry air (Airgas, zero grade, $0.83 \mathrm{~cm}^{3} \mathrm{~s}^{-1}$ per $10 \mathrm{mg}$ of wafer) at $673 \mathrm{~K}$ for $1 \mathrm{~h}$ through the cell.

2.3. Catalytic Rates and Selectivity Measurements. Ethanol oxidation rates and product selectivities were measured using a packed-bed quartz microreactor operated at $473-523 \mathrm{~K}$ and ambient pressure. The bed height in the reactor was $0.2-1 \mathrm{~cm}$ while the heated length was $15 \mathrm{~cm}$. The reactor was $32 \mathrm{~cm}$ long with an inner diameter of $1 \mathrm{~cm}$. It was heated by an electrical furnace regulated by a temperature controller (OMEGA). Temperature was measured with a K-type thermocouple inserted into the reactor and positioned within the catalyst bed. The catalyst $(0.02-0.1 \mathrm{~g} ; 250-500 \mu \mathrm{m})$ was diluted with equal amounts of acid-washed quartz granules to minimize bed temperature gradients. Each catalyst sample was treated in $10 \%$ $\mathrm{O}_{2}$ (Praxair, 99.999\%)/He (Praxair, 99.999\%) flowing at 1.67 $\mathrm{cm}^{3} \mathrm{~s}^{-1}$ by heating it to 723 at $0.083 \mathrm{~K} \mathrm{~s}^{-1}$ and then maintained at this temperature for $1 \mathrm{~h}$ before catalytic rate measurements. Ethanol oxidation was carried out using mixtures of $\mathrm{C}_{2} \mathrm{H}_{5} \mathrm{OH}$ (Sigma-Aldrich, 99.5\%) and premixed 90\% $\mathrm{O}_{2}-\mathrm{N}_{2}$ (Praxair, UHP) with $\mathrm{He}$ as a balance. The $\mathrm{O}_{2}$ and $\mathrm{He}$ flows were metered using Brooks 5850 series mass flow controllers. Ethanol and deionized water were introduced using a syringe pump (Cole Palmer, 74900 Series). All lines, valves, and connections were kept above $413 \mathrm{~K}$ to prevent condensation of reactants or products.

Reactant and product concentrations were measured using an online gas chromatograph (Hewlett-Packard 6890 GC) containing a methylsilicone capillary (HP-1, $50 \mathrm{~m} \times 0.25 \mathrm{~mm}$, $0.25 \mu \mathrm{m}$ film thickness) column and a Porapak Q (80-100 mesh, $1.8 \mathrm{~m} \times 3.2 \mathrm{~mm}$ ) packed column connected to a flame ionization and thermal conductivity detectors, respectively. Product selectivities are reported here as the percentage of the carbon atoms in the $\mathrm{C}_{2} \mathrm{H}_{5} \mathrm{OH}$ converted appearing within each product. Rates are reported as the molar $\mathrm{C}_{2} \mathrm{H}_{5} \mathrm{OH}$ conversion rate per mole of $\mathrm{V}$. The dynamics of the catalytic reaction were examined by varying residence time and partial pressures of the reactants. $\mathrm{C}_{2} \mathrm{H}_{5} \mathrm{OD}$ (Sigma-Aldrich, 99\%) and $\mathrm{C}_{2} \mathrm{D}_{5} \mathrm{OD}(\mathrm{CIL}$, Cambridge Isotope Laboratories, 99\%) were used as reactants to measure kinetic isotope effects.

2.4. In Situ Infrared Spectroscopy. Adsorbed species were characterized during ethanol oxidation catalysis by in situ infrared spectroscopy. A self-supported catalyst wafer $(\sim 5 \mathrm{mg}$ $\mathrm{cm}^{-2}$ ) was placed inside an infrared flow cell. Infrared spectra were recorded in transmission mode with $2 \mathrm{~cm}^{-1}$ resolution using a Nicolet Nexus 670 FTIR spectrometer equipped with a $\mathrm{Hg}-\mathrm{Cd}-\mathrm{Te}$ (MCT) detector. Before measuring spectra, catalysts were heated in a flow of $10 \% \mathrm{O}_{2}$ in $\mathrm{He}$ at $673 \mathrm{~K}$ for $1 \mathrm{~h}$ and then cooled to ambient temperature. Infrared spectra were recorded in a flow of $\mathrm{C}_{2} \mathrm{H}_{5} \mathrm{OH}$ (3 $\mathrm{kPa}$, Sigma-Aldrich, 99.5\%), $\mathrm{O}_{2}\left(8 \mathrm{kPa}, 90 \% \mathrm{O}_{2} /\right.$ balance $\mathrm{N}_{2}$, Praxair certified mixture), and $\mathrm{He}$ (Praxair, 99.999\%), at an ambient pressure and a total flow rate of $0.67 \mathrm{~cm}^{3} \mathrm{~s}^{-1}$ per $10 \mathrm{mg}$ of wafer. The sample was exposed to flowing gases at ambient temperatures, and the temperature was increased at $0.167 \mathrm{~K} \mathrm{~s}^{-1}$ to $573 \mathrm{~K}$ while acquiring spectra.

\section{Results and Discussion}

Table 1 provides a summary of V-content, BET surface areas, and nominal $\mathrm{VO}_{x}$ surface densities, together with a description of the notation used to designate all samples. $\mathrm{V}$ surface densities were calculated from the $\mathrm{V}_{2} \mathrm{O}_{5}$ content (assuming that all $\mathrm{V}$ in the impregnating solution remained in the sample) and the BET surface area. Table 1 shows that surface areas decreased from 115 to $84 \mathrm{~m}^{2} \mathrm{~g}^{-1}$ with increasing $\mathrm{VO}_{x}$ loading. These changes predominantly reflect the additional mass contributed by the $\mathrm{VO}_{x}$ species to each sample. BET surface areas per $\mathrm{Al}_{2} \mathrm{O}_{3}$ mass were essentially unaffected by impregnation and thermal treatments, except for the $15 \%$ wt. $\mathrm{VO}_{x} / \mathrm{Al}_{2} \mathrm{O}_{3}$ samples, which appear to show some pore occlusions as a result of larger $\mathrm{V}_{2} \mathrm{O}_{5}$ crystallites. ${ }^{4,24,25}$

The effects of $\mathrm{VO}_{x}$ surface density on UV-vis absorption edge energies are shown in Figure 1 for all samples, after treatment at $673 \mathrm{~K}$. We note that the intensity of the UV-vis spectral features increased with increasing V-content. All samples showed bands in the $2-4 \mathrm{eV}$ range, arising from $\mathrm{O}^{2-}$ to $\mathrm{V}^{5+}$ ligand-to-metal charge transfer processes. ${ }^{26} \mathrm{~V}^{4+}$ species show similar transitions at higher energies $(4.5-5 \mathrm{eV}),{ }^{27,28}$ but pre-edge features were not detected in any of the spectra. The absorption edge energy of semiconductor metal oxides depends on the size of oxide domains. ${ }^{23,29}$ Figure 1 shows that absorption edge energies decreased monotonically with $\mathrm{V}$ surface densities for values up to $11.8 \mathrm{~V} / \mathrm{nm}^{2}$ and then approached the value typical of large $\mathrm{V}_{2} \mathrm{O}_{5}$ crystallites $(\sim 2 \mathrm{eV}) .{ }^{4}$ This suggests that the energy necessary to promote an electron from the highest occupied molecular orbital in a lattice oxygen atom to the lowest unoccupied molecular orbital in a metal cation decreases as the $\mathrm{VO}_{x}$ surface density and domain size increased. These results are consistent with trends reported earlier for dispersed $\mathrm{MoO}_{x}$, $\mathrm{VO}_{x}$, and $\mathrm{WO}_{x}$ species on various inorganic supports. ${ }^{2,3,23,29,30}$ 


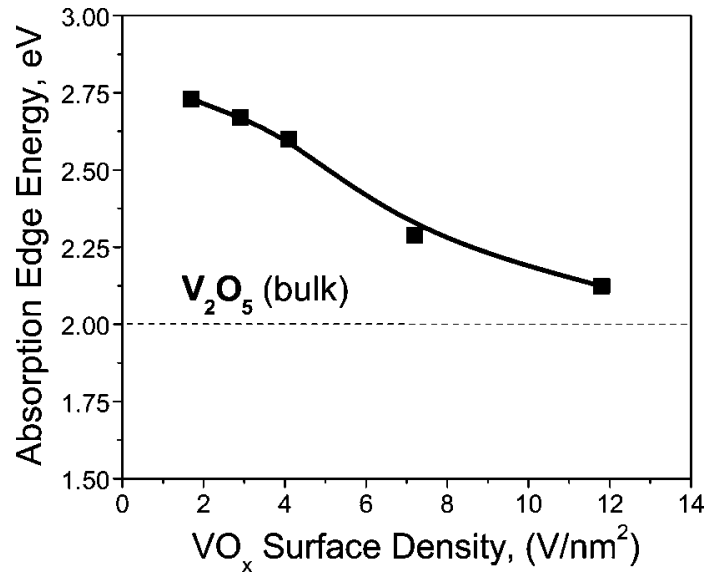

Figure 1. Dependence of the UV-vis absorption edge energy on the $\mathrm{VO}_{x}$ surface density. All spectra of $\mathrm{VO}_{x} / \mathrm{Al}_{2} \mathrm{O}_{3}$ samples were recorded under ambient conditions after dehydration treatment in a flow of $10 \%$ $\mathrm{O}_{2}$ in $\mathrm{He}$ at $673 \mathrm{~K}$ for $1 \mathrm{~h}$.

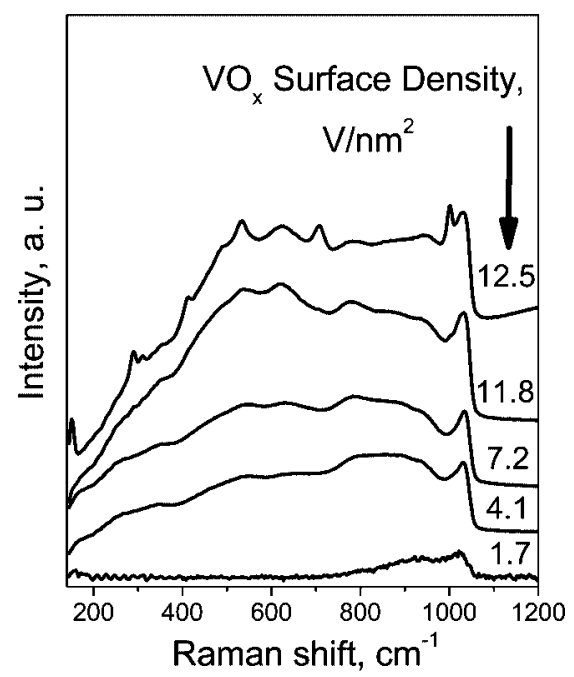

Figure 2. Raman spectra for $\mathrm{VO}_{x} / \mathrm{Al}_{2} \mathrm{O}_{3}$ catalysts obtained at $298 \mathrm{~K}$ in flowing $10 \% \mathrm{O}_{2}$ in $\mathrm{He}$ after treatment at $673 \mathrm{~K}$ for $1 \mathrm{~h}$.

Raman spectra measured at ambient temperature are shown in Figure 2 for samples with $1.7-12.5 \mathrm{~V} / \mathrm{nm}^{2}$ after treatment in dry air at $673 \mathrm{~K}$. The sample with the lowest V density (1.7 $\mathrm{V} / \mathrm{nm}^{2}$ ) exhibits a single band at $\sim 1024 \mathrm{~cm}^{-1}$ (Figure 2), which shifts to $1032 \mathrm{~cm}^{-1}$ with increasing $\mathrm{V}$ surface density. These bands are assigned to $V=\mathrm{O}$ stretching vibrations for isolated monovanadate species. ${ }^{31-33}$ Broad bands at $750-1000 \mathrm{~cm}^{-1}$ emerged with increasing $\mathrm{V}$ surface densities $\left(\sim 4.1 \mathrm{~V} / \mathrm{nm}^{2}\right)$; these have been attributed to $\mathrm{V}-\mathrm{O}-\mathrm{V}$ stretches in two-dimensional distorted polyvanadates. ${ }^{31-35}$ Polyvanadates become more evident as $\mathrm{V}$ surface density increased from 1.7 to $11.8 \mathrm{~V} / \mathrm{nm}^{2}$. Crystalline $\mathrm{V}_{2} \mathrm{O}_{5}$ was detected at higher $\mathrm{V}$ surface densities $\left(>7.2 \mathrm{~V} / \mathrm{nm}^{2}\right)$ by its Raman bands at 1000, 706, 532, 489, 410, $305,287,203,150 \mathrm{~cm}^{-1}$. ${ }^{36}$ The fraction of $\mathrm{V}$ present as $\mathrm{V}_{2} \mathrm{O}_{5}$ is very small even at high surface densities, since these bands are relatively weak and scattering cross sections for $\mathrm{V}_{2} \mathrm{O}_{5}$ crystallites are $\sim 10$ times larger than for monovanadate and polyvanadate species. ${ }^{37}$ Raman and UV-visible spectra indicate that samples with $\mathrm{V}$ surface densities of $1.7-7.2 \mathrm{~V} / \mathrm{nm}^{2}$ consist of $\mathrm{Al}_{2} \mathrm{O}_{3}$ surfaces covered by increasing amounts of twodimensional polyvanadates and decreasing amounts of monovanadate species. The incipient formation of three-dimensional $\mathrm{V}_{2} \mathrm{O}_{5}$ cluster domains was detected at $\mathrm{V}$ surface densities above $7.2 \mathrm{~V} / \mathrm{nm}^{2}$.

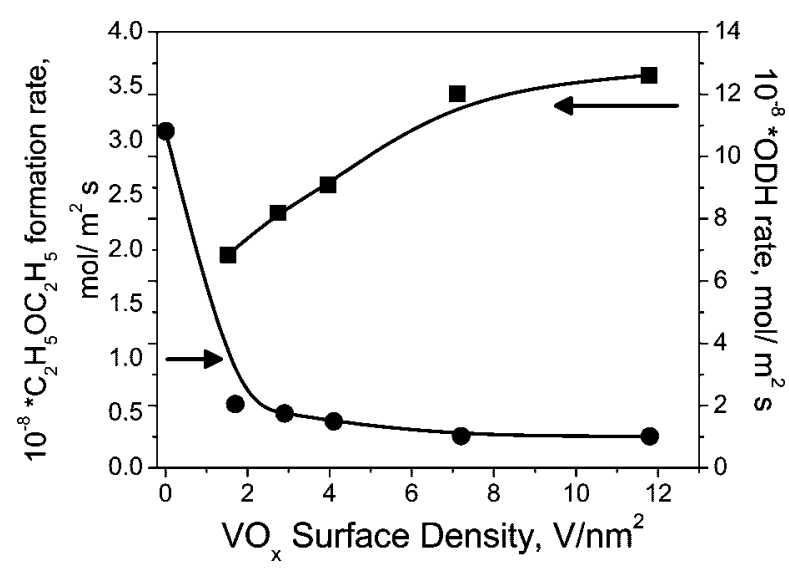

Figure 3. ODH rates (ם) and diethyl ether formation rates ( normalized per unit catalyst surface area as a function of vanadia surface density on $\mathrm{VO}_{x} / \mathrm{Al}_{2} \mathrm{O}_{3} ; 4 \mathrm{kPa} \mathrm{C} \mathrm{H}_{5} \mathrm{OH}, 9 \mathrm{kPa} \mathrm{O}$, He balance, $473 \mathrm{~K}$, $\sim 10 \%$ conversion.

Ethanol oxidation turnover rates (per V-atom) and selectivities were measured on samples with $1.7-11.8 \mathrm{~V} / \mathrm{nm}^{2}$ surface densities at $473-523 \mathrm{~K}$. Ethanol oxidation to acetaldehyde and dehydration to diethyl ether occurred in parallel. Acetaldehyde forms on dispersed vanadia domains. Initial selectivities to acetaldehyde (extrapolated to zero conversion) increased monotonically with $\mathrm{VO}_{x}$ surface density, from $52 \%$ on $3 \%$ wt. $\mathrm{VO}_{x} /$ $\mathrm{Al}_{2} \mathrm{O}_{3}$ to $79.5 \%$ on $15 \%$ wt. $\mathrm{VO}_{x} / \mathrm{Al}_{2} \mathrm{O}_{3}$. The amounts of acetaldehyde formed on alumina were $\sim 10$ times smaller than on the sample with the lowest $\mathrm{V}$ content $\left(1.5 \times 10^{-7} \mathrm{~mol} \mathrm{~g}^{-1}\right.$ cat. $\mathrm{s}^{-1}$ for $\mathrm{Al}_{2} \mathrm{O}_{3}$ vs $1.7 \times 10^{-6} \mathrm{~mol} \mathrm{~g}^{-1}$ cat. $\mathrm{s}^{-1}$ for $3 \% \mathrm{wt}$. $\mathrm{VO}_{x} / \mathrm{Al}_{2} \mathrm{O}_{3}$ ). Diethyl ether forms via bimolecular dehydration reactions of ethanol catalyzed by Lewis or Brønsted acid sites on exposed $\mathrm{Al}_{2} \mathrm{O}_{3}$ surfaces. ${ }^{38,39}$

Figure 3 shows the effects of vanadia surface density on the areal rates of formation of acetaldehyde and diethyl ether at $\sim 10 \% \mathrm{C}_{2} \mathrm{H}_{5} \mathrm{OH}$ conversions. The rate of acetaldehyde formation $(\mathrm{ODH})$ increased with increasing $\mathrm{VO}_{x}$ surface density and reached a plateau at a surface density of $7.2 \mathrm{~V} / \mathrm{nm}^{2}$. In contrast, the areal rate of diethyl ether formation decreased monotonically with increasing coverage of $\mathrm{Al}_{2} \mathrm{O}_{3}$ support surfaces by $\mathrm{VO}_{x}$ domains, as a result of the titration of the $\mathrm{Al}_{2} \mathrm{O}_{3}$ acid sites required for ethanol dehydration. The constant areal $\mathrm{ODH}$ rates observed above $7.2 \mathrm{~V} / \mathrm{nm}^{2}$ reflect the formation of a $\mathrm{VO}_{x}$ monolayer on support surfaces. Diethyl ether formation rates decreased markedly down to $1.8 \mathrm{~V} / \mathrm{nm}^{2}$ and only slightly thereafter, suggesting that acid sites on $\mathrm{Al}_{2} \mathrm{O}_{3}$ supports are titrated by $\mathrm{VO}_{x}$ species at coverages well below those required to form a polyvanadate monolayer (a theoretical monolayer of polyvanadate species occurs at $7.0 \mathrm{~V} / \mathrm{nm}^{2}$ and at $2.3 \mathrm{~V} / \mathrm{nm}^{2}$ for monovanadate species). ${ }^{2}$ The low dehydration rates on samples with more than $1.8 \mathrm{~V} / \mathrm{nm}^{2}$ reflect either residual sites on alumina or weak Brønsted sites on $\mathrm{VO}_{x}$ domains.

The initial turnover rates (per V atom; extrapolated to zero residence time) for acetaldehyde synthesis are shown as a function of vanadia surface density at various temperatures $(473-523 \mathrm{~K})$ in Figure 4 . At $473 \mathrm{~K}$, turnover rates increased initially with increasing $\mathrm{VO}_{x}$ surface density, reached a maximum value $\left(8.1 \times 10^{-3} \mathrm{~mol} / \mathrm{mol} \cdot \mathrm{V} \cdot \mathrm{s}\right)$ at a surface density of $\sim 7.2 \mathrm{~V} / \mathrm{nm}^{2}$, and then decreased at higher $\mathrm{VO}_{x}$ surface densities. Below $7.2 \mathrm{~V} / \mathrm{nm}^{2}$, the alumina surface is covered predominantly by monovanadate and polyvanadate species, and all $\mathrm{V}$ atoms are accessible to reactants. Consequently, the modest initial increase in turnover rates must reflect a higher surface reactivity of polyvanadate species relative to monovanadate structures. 


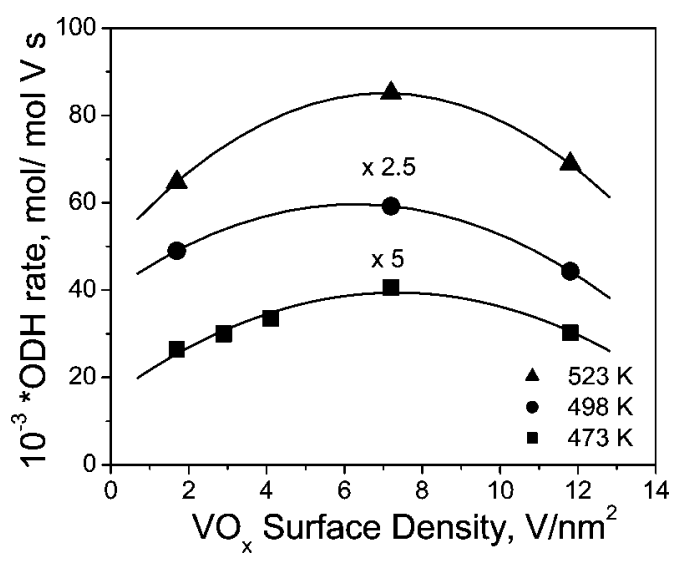

Figure 4. Initial $\mathrm{ODH}$ rates as a vanadia surface density on $\mathrm{VO}_{x} /$ $\mathrm{Al}_{2} \mathrm{O}_{3}$ at different temperatures $(\boldsymbol{\square}, 473 \mathrm{~K} ; \boldsymbol{\bullet}, 498 \mathrm{~K} ; \boldsymbol{\Delta}, 523 \mathrm{~K}), 4$ $\mathrm{kPa} \mathrm{C}_{2} \mathrm{H}_{5} \mathrm{OH}, 9 \mathrm{kPa} \mathrm{O}$, He balance, extrapolated to zero residence time.

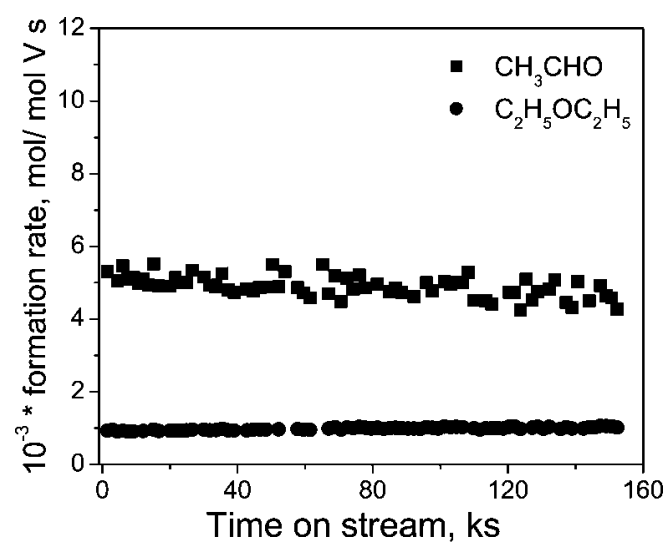

Figure 5. Stability of $10.5 \%$ wt. $\mathrm{VO}_{x} / \mathrm{Al}_{2} \mathrm{O}_{3}, 7.2 \mathrm{~V} / \mathrm{nm}^{2}$ during ethanol oxidation: $3 \mathrm{kPa} \mathrm{C}_{2} \mathrm{H}_{5} \mathrm{OH}, 8 \mathrm{kPa} \mathrm{O}$, He balance, $473 \mathrm{~K}$.

Similar effects of domain size have been reported for ethane and propane $\mathrm{ODH}$ reactions on alumina-supported $\mathrm{VO}_{x}$ and $\mathrm{MoO}_{x}$ domains. ${ }^{3,4,40} \mathrm{VO}_{x}$ domains of intermediate size provide a compromise between the reactivity and the accessibility of lattice oxygen atoms, which are involved in kinetically relevant $\mathrm{H}$-abstraction from alkanes ${ }^{4,34}$ and, as we show later, also from ethoxide intermediates to form acetaldehyde. Above $7.2 \mathrm{~V} / \mathrm{nm}^{2}$, the deposited vanadia forms an increasing number of threedimensional domains, with a concomitant decrease in the accessibility of $\mathrm{V}$ atoms. Similar trends were observed at higher temperatures $(498-523 \mathrm{~K})$. $\mathrm{ODH}$ reaction rates on $\mathrm{VO}_{x} / \mathrm{Al}_{2} \mathrm{O}_{3}$ catalysts increased with increasing reaction temperature (Figure 4). $\mathrm{CO}$ and $\mathrm{CO}_{2}$ were not detected at $473 \mathrm{~K}$ on any of the catalysts tested and $\mathrm{CO}_{x}$ selectivities were $<2 \%$ even at $523 \mathrm{~K}$.

The mechanism and kinetics of ethanol oxidation to acetaldehyde were investigated on $10.5 \%$ wt. $\mathrm{VO}_{x} / \mathrm{Al}_{2} \mathrm{O}_{3}$ with 7.2 $\mathrm{V} / \mathrm{nm}^{2}$ surface density. This catalyst was chosen because of its low reactivity for parallel acid-catalyzed reactions, indicative of near-monolayer $\mathrm{VO}_{x}$ coverages. This sample exhibited stable activity for ethanol oxidation to acetaldehyde at $473 \mathrm{~K}$ for $40 \mathrm{~h}$ with low diethyl ether formation rates (Figure 5). Figure 6A shows the effects of ethanol pressure (1-9 kPa; $473 \mathrm{~K})$ on $\mathrm{ODH}$ rates extrapolated to zero residence time. Rates depended weakly on ethanol pressure, suggesting that ethanol-derived reactive intermediates (e.g., $\mathrm{C}_{2} \mathrm{H}_{5} \mathrm{O}^{-}$) are present at near-saturation coverages and are the most abundant reactive intermediates. The effects of $\mathrm{O}_{2}$ pressure $(2-32 \mathrm{kPa})$ on $\mathrm{ODH}$ rates are shown in Figure $6 \mathrm{~B}\left(3 \mathrm{kPa} \mathrm{C}_{2} \mathrm{H}_{5} \mathrm{OH}, 473 \mathrm{~K}\right)$. The solid line shown in
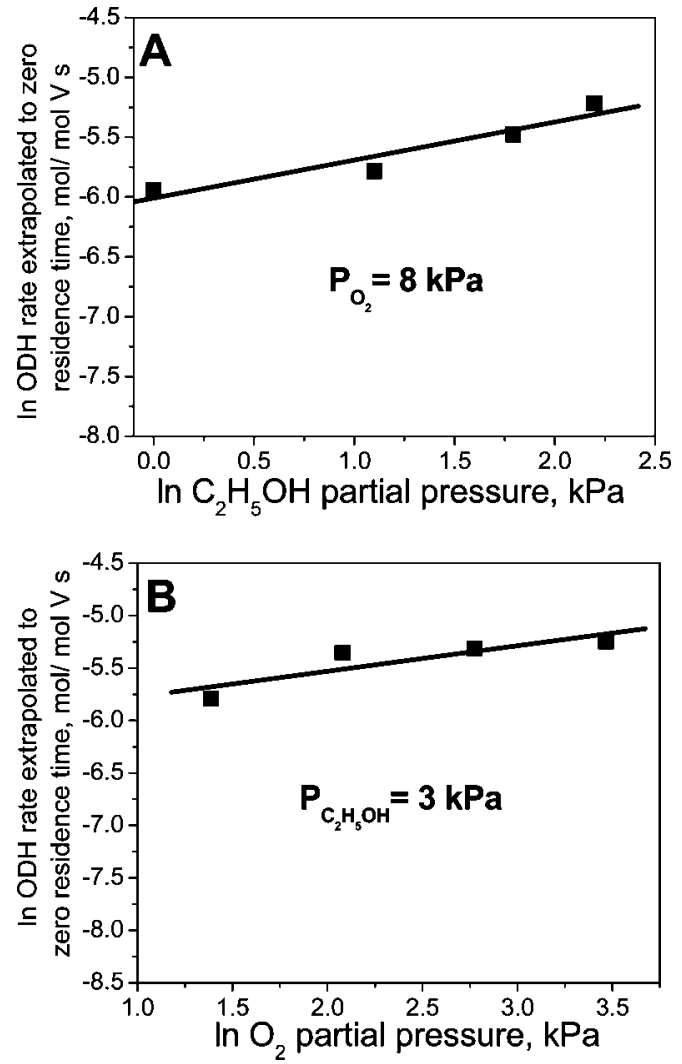

Figure 6. Effect of ethanol (A) and oxygen (B) partial pressures on rates of oxidative dehydrogenation: $10.5 \% \mathrm{wt} . \mathrm{VO}_{x} / \mathrm{Al}_{2} \mathrm{O}_{3}, 7.2 \mathrm{~V} / \mathrm{nm}^{2}$, $473 \mathrm{~K}$.

this figure has been added as a guide. Rates increased weakly with $\mathrm{O}_{2}$ pressure below $4 \mathrm{kPa}$ and became independent of $\mathrm{O}_{2}$ pressure at higher values. These data indicate that $\mathrm{VO}_{x}$ species are fully oxidized during ethanol $\mathrm{ODH}$ catalysis and that $\mathrm{ODH}$ rates are limited by slow reduction steps, presumably involving the oxidation of ethoxide intermediates via $\mathrm{H}$-abstraction. The addition of water to the reaction feed $(1-5 \mathrm{kPa})$ did not influence the rate of ethanol ODH, contrary to what is observed for the ODH reactions of alkanes, for which water vapor, even at low concentrations, inhibits reaction rates. ${ }^{4}$ In the case of alkane ODH the concentration of alkoxide species on the catalyst surface is very small because the rate of alkane activation to form alkoxides is rate-limiting. As a result, water can readily access the surface and adsorb. In contrast, during ethanol oxidation the catalyst surface is saturated with ethoxide species, and therefore water needs to compete for adsorption sites.

The kinetics of ethanol oxidation to acetaldehyde can be interpreted in terms of the sequence of elementary steps depicted in Scheme 1. Ethanol adsorbs dissociatively on $\mathrm{V}$ centers to form adsorbed ethoxide species and $\mathrm{OH}$ groups in a quasiequilibrated step. Scheme 1 depicts this process as it would occur via interactions with $\mathrm{V}-\mathrm{O}-\mathrm{V}$ bonds, but it could also occur by involvement of $\mathrm{V}-\mathrm{O}-\mathrm{Al}$ bonds, ${ }^{41}$ without detectable consequences for the reaction kinetics. Acetaldehyde forms in a subsequent step via $\mathrm{H}$-abstraction from ethoxide species and desorption. The $\mathrm{OH}$ species concurrently formed ultimately recombine with another $\mathrm{OH}$ to form $\mathrm{H}_{2} \mathrm{O}$. The lack of inhibition by $\mathrm{H}_{2} \mathrm{O}$ makes reversibility of water desorption (step 4) inconsequential in the kinetic expression. The oxygen vacancies, formed via dehydroxylation, are reoxidized via irreversible chemisorption of $\mathrm{O}_{2}$ to complete the catalytic cycle. ${ }^{4}$ Previous work on methanol oxidation suggests that reoxidation proceeds via adsorption of $\mathrm{O}_{2}$ at a vacancy site to form a peroxide species. 


\section{SCHEME 1}

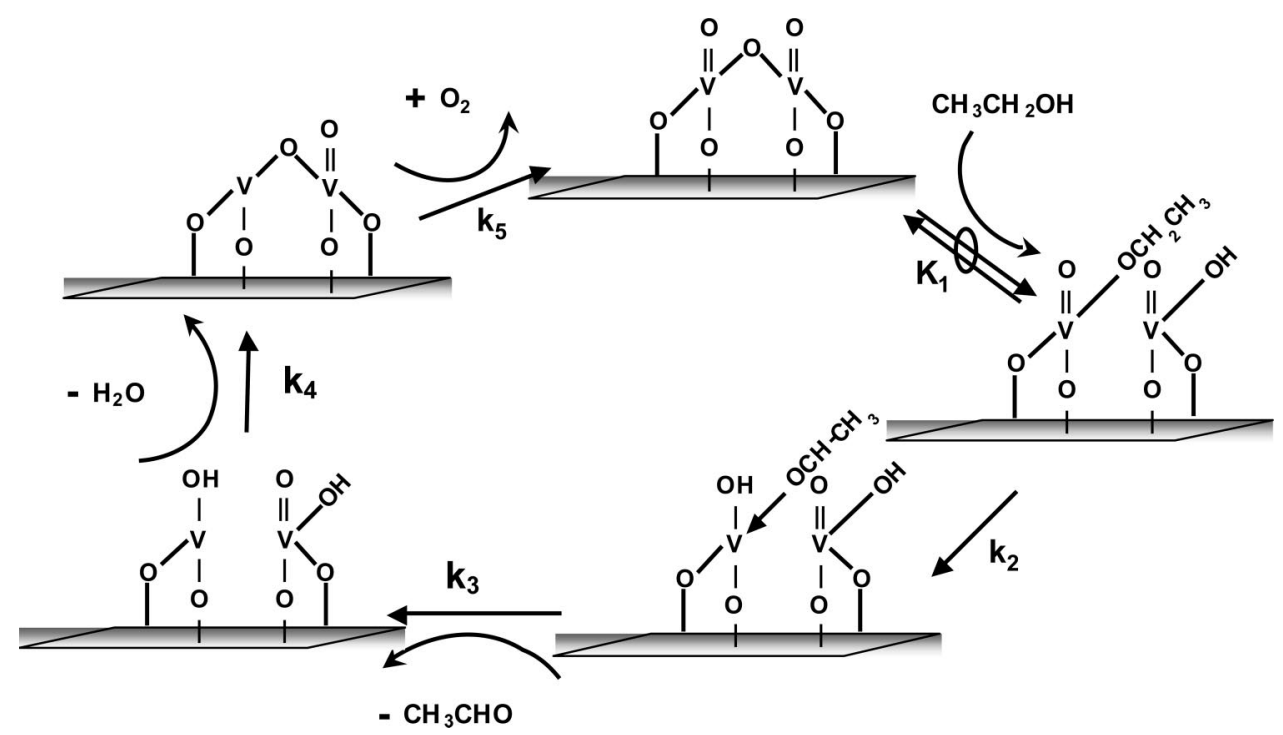

One of the two $\mathrm{O}$ atoms eliminates the vacancy, while the other $\mathrm{O}$ atom migrates through the near surface region until it reaches and reoxidixe a second vacancy. ${ }^{42}$

The irreversible nature of $\mathrm{O}_{2}$ dissociation on surface vacancies (step 5) was probed by measuring the rate of formation of mixed ${ }^{18} \mathrm{O}^{16} \mathrm{O}$ isotopomers during $\mathrm{C}_{2} \mathrm{H}_{5}{ }^{16} \mathrm{OH}$ reactions with equimolar ${ }^{18} \mathrm{O}_{2}-{ }^{16} \mathrm{O}_{2}$ mixtures. Reversible dissociation steps would lead to rapid isotopic equilibration, while irreversible steps would maintain the bimodal isotopic distribution in the ${ }^{16} \mathrm{O}_{2}-{ }^{18} \mathrm{O}_{2}$ reactants. No ${ }^{18} \mathrm{O}^{16} \mathrm{O}$ isotopomers were detected in the reactor effluent at any ethanol conversion $(0-15 \%)$, indicating that $\mathrm{O}_{2}$ dissociation is irreversible at $473 \mathrm{~K}$. Transient-response experiments conducted in the absence of $\mathrm{O}_{2}$ confirmed that $\mathrm{C}_{2} \mathrm{H}_{5} \mathrm{OH}$ oxidation to $\mathrm{CH}_{3} \mathrm{CHO}$ requires lattice oxygen atoms instead of adsorbed oxygen. The initial rates of anaerobic oxidation of ethanol on oxidized $10.5 \%$ wt. $\mathrm{VO}_{x} / \mathrm{Al}_{2} \mathrm{O}_{3}$ catalyst were $2 \times$ $10^{-3} \mathrm{~mol} / \mathrm{mol} \mathrm{V} \mathrm{s}$, in reasonable agreement with the rates measured in the presence of $\mathrm{O}_{2}\left(8.1 \times 10^{-3} \mathrm{~mol} / \mathrm{mol} \mathrm{V} \mathrm{s}\right)$ at $473 \mathrm{~K}$.

A pseudosteady state analysis of the elementary steps in Scheme 1 gives a rate equation of the form:

$$
r=\frac{\frac{1}{2} k_{2} K_{1} P_{\mathrm{C}_{2} \mathrm{H}_{5} \mathrm{OH}}}{1+K_{1} P_{\mathrm{C}_{2} \mathrm{H}_{5} \mathrm{OH}}+\frac{K_{1} k_{2} P_{\mathrm{C}_{2} \mathrm{H}_{5} \mathrm{OH}}}{2 k_{5} P_{\mathrm{O}_{2}}}}
$$

In eq $1, K_{1}$ is the equilibrium constant for ethanol adsorption, $k_{2}$ is the rate constant for $\mathrm{H}$-abstraction from adsorbed ethoxide species, and $k_{5}$ is the rate constant for the reoxidation of vanadium sites. This equation becomes a weak function of ethanol pressure when the $K_{1} P_{\mathrm{C}_{2} \mathrm{H}_{5} \mathrm{OH}}$ terms become larger than unity. The near zero-order in oxygen partial pressure suggests that the third term in the denominator is much smaller than the second term because $k_{2} /\left(2 k_{5} P_{\mathrm{O}_{2}}\right) \ll 1.0$. Therefore, we conclude that the rate is approximately equal to $k_{2} / 2$ for the conditions of our experiments. An activation energy of $94 \mathrm{~kJ} / \mathrm{mol}$ for $\mathrm{H}$-abstraction from ethoxide intermediates (step 2 in Scheme 1) was determined from an Arrhenius plot of $\ln \left(k_{2}\right)$ versus $1 / T$.

Isotopic studies with D-labeled ethanol were used to confirm these mechanistic hypotheses. Table 2 lists kinetic isotope effects (KIE, e.g. $r_{\mathrm{C}_{2} \mathrm{H}_{5} \mathrm{OH}} / r_{\mathrm{C}_{2} \mathrm{D}_{5} \mathrm{OD}}$ ) measured using $\mathrm{C}_{2} \mathrm{H}_{5} \mathrm{OH}, \mathrm{C}_{2} \mathrm{H}_{5} \mathrm{OD}$, or $\mathrm{C}_{2} \mathrm{D}_{5} \mathrm{OD}(3 \mathrm{kPa})$ with $\mathrm{O}_{2}$ coreactants $(8 \mathrm{kPa})$ at $473 \mathrm{~K}$. The
TABLE 2: Kinetic Isotope Effects for Ethanol Oxidation on $10.5 \%$ wt. $\mathrm{VO}_{x} / \mathrm{Al}_{2} \mathrm{O}_{3}$ at $473 \mathrm{~K}^{a}$

\begin{tabular}{lcc}
\hline & $\begin{array}{c}\text { ODH rate, } \\
10^{-3} * \text { mol/ mol V -s }\end{array}$ & $\begin{array}{c}\mathrm{C}_{2} \mathrm{H}_{5} \mathrm{OC}_{2} \mathrm{H}_{5} \\
\text { formation rate, } \\
10^{-3} * \text { mol/ mol V -s }\end{array}$ \\
\hline $\mathrm{C}_{2} \mathrm{H}_{5} \mathrm{OH}$ & 7.9 & 1.1 \\
$\mathrm{C}_{2} \mathrm{H}_{5} \mathrm{OD}$ & 7.8 & 1.0 \\
$\mathrm{C}_{2} \mathrm{D}_{5} \mathrm{OD}$ & 1.6 & 0.9 \\
$k_{\mathrm{C}_{2} \mathrm{H}_{5} \mathrm{OH}} / k_{\mathrm{C}_{2} \mathrm{H}_{5} \mathrm{OD}}$ & 1.02 & 1.1 \\
$k_{\mathrm{C}_{2} \mathrm{H}_{5} \mathrm{OH}} / k_{\mathrm{C}_{2} \mathrm{D}_{5} \mathrm{OD}}$ & 4.9 & 1.2
\end{tabular}

a $7.2 \mathrm{~V} / \mathrm{nm}^{2}, 3 \mathrm{kPa} \mathrm{C}_{2} \mathrm{H}_{5} \mathrm{OH}, 8 \mathrm{kPa} \mathrm{O}$, He balance, $\sim 5-6 \%$ ethanol conversion, ethylene selectivity was $\sim 1 \%$.

KIE for $\mathrm{C}_{2} \mathrm{H}_{5} \mathrm{OD}$ is 1.02 , consistent with quasiequilibrated ethanol adsorption. In contrast, $\mathrm{C}_{2} \mathrm{D}_{5} \mathrm{OD}$ reactants gave $\mathrm{KIE}$ values of $\sim 5$, as expected from rates limited by the activation of $\mathrm{C}-\mathrm{H}$ bonds. Taken together, these results indicate that activation of $\mathrm{O}-\mathrm{H}$ bonds is equilibrated and activation of $\mathrm{C}-\mathrm{H}$ bonds is involved in the kinetically relevant steps for ethanol oxidation on dispersed $\mathrm{VO}_{x}$ domains.

The corresponding kinetic isotope effects for the formation of diethyl ether are shown in Table 2. The KIE is 1.1 for $\mathrm{C}_{2} \mathrm{H}_{5} \mathrm{OH}$ vs $\mathrm{C}_{2} \mathrm{H}_{5} \mathrm{OD}$ and 1.2 for $\mathrm{C}_{2} \mathrm{H}_{5} \mathrm{OH}$ vs $\mathrm{C}_{2} \mathrm{D}_{5} \mathrm{OD}$. This suggests that cleavage of the $\mathrm{O}-\mathrm{H}$ bond is not involved in the rate-limiting step for diethyl ether formation; it is likely that the critical step involves $\mathrm{C}-\mathrm{O}$ bond cleavage ${ }^{43}$ Similar behavior was observed previously for $\mathrm{MoO}_{3} / \mathrm{Al}_{2} \mathrm{O}_{3}$ during ethanol oxidation reaction. ${ }^{43}$

The formation of adsorbed species during oxidative dehydrogenation of ethanol and their subsequent reactions in the presence of $\mathrm{O}_{2}$ were examined by infrared spectroscopy at $300-573 \mathrm{~K}$. Contact of $\mathrm{VO}_{x} / \mathrm{Al}_{2} \mathrm{O}_{3} \quad\left(7.2 \mathrm{~V} / \mathrm{nm}^{2}\right)$ with ethanol $-\mathrm{O}_{2}$ mixtures at $298 \mathrm{~K}$ led to infrared bands at 2974 , 2931, 2900, 2874, 1170, 1264, 1388, $1450 \mathrm{~cm}^{-1}$ (Figure 7). The bands at 2970 and $2870 \mathrm{~cm}^{-1}$ arise from $v_{\mathrm{a}}\left(\mathrm{CH}_{3}\right)$ and $v_{\mathrm{s}}\left(\mathrm{CH}_{3}\right)$ vibrations, respectively, and the bands near $2930 \mathrm{~cm}^{-1}$ and $2900 \mathrm{~cm}^{-1}$ from $v_{\mathrm{a}}\left(\mathrm{CH}_{2}\right)$ and $v_{\mathrm{s}}\left(\mathrm{CH}_{2}\right)$ modes, respectively, in ethoxide species. ${ }^{4-46}$ Similar bands were also detected on pure alumina during ethanol reaction. For the sample with 7.2 $\mathrm{V} / \mathrm{nm}^{2}$, virtually all of the alumina sites have been covered with $\mathrm{VO}_{x}$, and hence the bands that we detected arise predominantly from ethoxide species on vanadia.

The intensity of the $\mathrm{C}-\mathrm{H}$ stretching band evident in Figure 7 decreased with increasing temperature (298-573 K), and new 


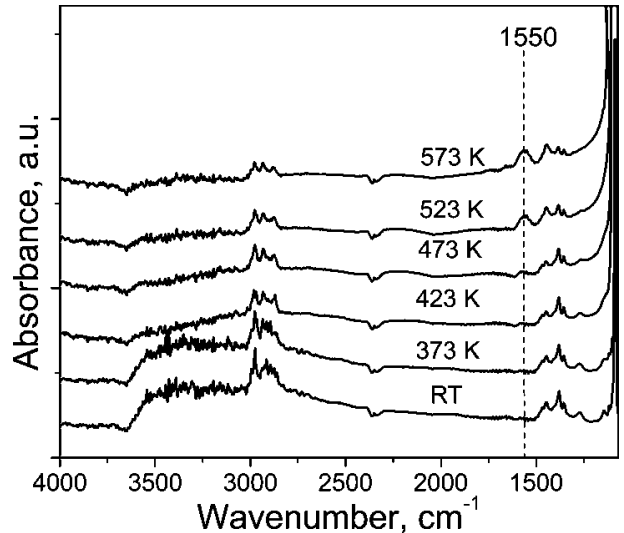

Figure 7. FTIR spectra during selective oxidation of ethanol (3 $\mathrm{kPa}$ $\mathrm{C}_{2} \mathrm{H}_{5} \mathrm{OH}, 8 \mathrm{kPa} \mathrm{O}$, He balance).

bands appeared at $\sim 1550$ and $1468 \mathrm{~cm}^{-1}$ at $\sim 473 \mathrm{~K}$. The latter features increased in intensity with increasing temperature and are attributed to acetate species. ${ }^{44,45,47,48}$ The decrease in the intensity of the broad feature seen between $3700 \mathrm{~cm}^{-1}$ and 3000 $\mathrm{cm}^{-1}$ together with the decrease in intensity of the sharp band seen just below $3000 \mathrm{~cm}^{-1}$ is likely to arise from the desorption of molecularly adsorbed ethanol as the temperature increased from 298 to $423 \mathrm{~K}$. The decrease in the intensity of the bands attributed to ethoxide species with increasing temperature is small, consistent with the conclusion based on analysis of rate data (see above) that the surface of the catalyst is saturated by ethoxide species.

The mechanism of ethanol oxidation to acetaldehyde on $\mathrm{VO}_{x} /$ $\mathrm{Al}_{2} \mathrm{O}_{3}$ proposed here resembles that previously proposed for methanol oxidation to formaldehyde. ${ }^{42,47,48}$ However, the rate of methanol oxidation is proportional to methanol and independent of $\mathrm{O}_{2}$ pressure, whereas the rate of ethanol oxidation is independent of both ethanol and $\mathrm{O}_{2}$ pressure. This difference merely reflects the lower coverages of methoxides prevalent at reaction conditions relative to those of ethoxide. Ethanol forms ethoxides at near saturation coverages because the adsorption constant for ethanol is higher than that for methanol and the temperature for ethanol oxidation is lower than that for methanol oxidation.

The weak effects of $\mathrm{VO}_{x}$ surface density on ODH turnover rates ( $\sim 1.5$ factor; $473 \mathrm{~K}$, Figure 4$)$ appears to reflect differences in the specific activity and reducibility between monovanadate and polyvanadate species or an increase in the size of polyvanadate domains. These trends are similar to those observed in the ODH of ethane and propane determined for zero alkane conversion. ${ }^{4}$ The notable difference between the ODH of ethanol and the $\mathrm{ODH}$ of light alkanes is the degree of increase between the specific rate of ODH for the lowest $\mathrm{VO}_{x}$ surface density and that observed for monolayer coverage. For the latter reaction, the ratio between the highest and the lowest specific rate is $\sim 4$ for temperatures of $663 \mathrm{~K}^{4}$

\section{Conclusions}

Raman and UV-visible spectroscopy showed that for V surface densities in the range of $1.7-7.2 \mathrm{~V} / \mathrm{nm}^{2}$, the surface of $\mathrm{Al}_{2} \mathrm{O}_{3}$ is covered to an increasing extent by two-dimensional polyvanadate species and to a lesser extent by monovanadate species; the incipient formation of three-dimensional $\mathrm{V}_{2} \mathrm{O}_{5}$ clusters domains was detected at higher $\mathrm{V}$ surface densities. The acetaldehyde formation rates during ethanol oxidation on $\mathrm{VO}_{x} / \mathrm{Al}_{2} \mathrm{O}_{3}$ catalysts depend on vanadia surface densities. Polyvanadate species supported on alumina exhibit somewhat higher rates of ethanol ODH than monovanadate species. The kinetics of ethanol ODH are nearly zero-order in both ethanol and oxygen partial pressures, suggesting that the surface of the supported vanadia is saturated with adsorbed ethanol and that the rate of catalyst oxidation is much higher than the rate of catalyst reduction. Kinetic and isotopic studies are consistent with a reduction-oxidation catalytic cycle requiring lattice oxygen atoms and limited by $\mathrm{C}-\mathrm{H}$ bond activation of adsorbed ethoxide species.

Acknowledgment. This work was supported by the Director, Office of Basic Energy Sciences, Chemical Sciences Division of the US Department of Energy under Contract DE-AC0376 SF00098.

\section{References and Notes} 211.

(1) Wainwright, M. S.; Foster, N. R. Catal. Rev. Sci. Eng. 1979, 19, (2) Khodakov, A.; Yang, J.; Su, S.; Iglesia, E.; Bell, A. T. J. Catal. 1998, 177, 343 .

(3) Khodakov, A.; Olthof, B.; Bell, A. T.; Iglesia, E. J. Catal. 1999, 181,205

(4) Argyle, M. D.; Chen, K.; Bell, A. T.; Iglesia, E. J. Catal. 2002, 208,139 210 .

(5) Steinfeldt, N.; Muller, D.; Berndt, H. Appl. Catal., A 2004, 272,

(6) Forzatti, P.; Tronconi, E.; Elmi, A. S.; Busca, G. Appl. Catal., A 1997, 157, 387.

(7) Ilchenko, N. I.; Hanke, W.; Rayevskaya, L. N.; Golodets, G. I.; Öhlmann, G. React. Kinet. Catal. Lett. 1990, 41, 147.

1,245

(8) Cavelli, P.; Cavani, F.; Manenti, I.; Trifiro, F. Catal. Today 1987,

(9) Bosch, H.; Janssen, F. Catal. Today 1988, 2, 369.

(10) Quarantana, N. E.; Soria, J.; Cortés Croberán, V.; Fierro, J. L. G. J. Catal. 1997, 171, 13.

(11) Miller, J. M.; Lakshimi, L. J. J. Catal. 1999, 184, 68.

(12) Lakshimi, J. L.; Jones, T. R. B.; Gurgi, M.; Milller, J. M. J. Mol. Catal. A: Chem. 2000, 152, 99.

(13) Rodella, C. B.; Franco, R. W. A.; Magon, C. J.; Donso, J. P.; Nunes, L. A. O.; Saeki, M. J.; Aegerter, M. A.; Florentino, A. O. J. Sol-Gel Sci. Technol. 2002, 25, 75 .

(14) Lin, H.-M.; Kao, S.-T.; Lin, K.-M.; Chang, J.-R.; Shyu, S.-G. J. Catal. 2004, 224, 156.

(15) Tesser, R.; Maradei, V.; Di Serio, M.; Santacesaria, E. Ind. Eng. Chem. Res. 2004, 43, 1623.

(16) Kwak, J. H.; Herrera, J. E.; Hu, J. Z.; Wnag, Y.; Peden, C. H. F. Appl. Catal., A 2006, 300, 109.

(17) Gucbilmez, Y.; Dogu, T.; Balci, S. Ind. Eng. Chem. Res. 2006, 45, 3496.

(18) Chimentao, R. J.; Herrera, J. E.; Kwak, J. H.; Medina, F.; Wang, Y.; Peden, C. H. F. Appl. Catal., A 2007, 332, 263.

(19) Lin, Y.-C.; Chang, C.-H.; Chen, C.-C.; Jehng, J.-M.; Shyu, S.-G. Catal. Commun. 2008, 9, 675.

(20) Li, X.; Iglesia, E. Chem. Eur. J. 2007, 13, 9324.

(21) Oyama, S. T.; Samorjai, G. A. J. Phys. Chem. 1990, 94, 5022.

(22) Inumaru, K.; Misono, M.; Okuhara, T. Appl. Catal., A 1997, 149, 133.

(23) Barton, D. G.; Shtein, M.; Wilson, R. D.; Soled, S. L.; Iglesia, E. J. Phys. Chem. B 1999, 103, 630.

(24) Yang, S.; Iglesia, E.; Bell, A. T. J. Phys. Chem. B 2005, 109, 8987.

(25) Rao, T. V. M.; Deo, G. AIChE J. 2007, 53, 1538.

(26) Iwamoto, M.; Furukawa, H.; Matsukami, K.; Takenaka, T.; Kagawa,

S. J. Amer. Chem. Soc. 1983, 105, 3719.

(27) Alivisatos, A. P. Science 1996, 271, 933.

(28) Liu, Z.; Davis, R. J. J. Phys. Chem. 1986, 90, 2555.

(29) Weber, R. S. J. Catal. 1995, 151, 470.

(30) Gao, X.; Wachs, I. E. J. Phys. Chem. B 2000, 104, 1261.

(31) Wachs, I. E. Catal. Today 1996, 27, 437.

(32) Olthof, B.; Khodakov, A.; Bell, A. T.; Iglesia, E. J. Phys. Chem. B 2000, 104, 1516.

(33) Vuurman, M. A.; Wachs, I. E. J. Phys. Chem. 1992, 96, 5008.

(34) Chen, K.; Iglesia, E.; Bell, A. T. J. Catal. 2000, 192, 197.

(35) Deo, G.; Wachs, I. E. J. Phys. Chem. 1999, 95, 5889.

(36) Kung, H. H. Adv. Catal. 1994, 40, 1.

(37) Dai, H.; Bell, A. T.; Iglesia, E. J. Catal. 2004, 221, 491.

(38) Avgouropoulos, G.; Oikonmopoulos, E.; Kanistras, D.; Ioannides, T. Appl. Catal., B 2006, 65, 62.

(39) Rejesh, H.; Ozkan, U. S. Ind. Eng. Chem. Res. 1993, 32, 1622. 
(40) Chen, K.; Xie, S.; Bell, A. T.; Iglesia, E. J. Catal. 2001, 198, 232.

(41) Kim, T.; Wachs, I. E. J. Catal. 2008, 255, 197.

(42) Goodrow, A.; Bell, A. T. J. Phys. Chem. C 2007, 111, 14753.

(43) Zhang, W.; Oyama, S. T. J. Phys. Chem. 1996, 100, 10759.

(44) del Arco, M.; Carriazo, D.; Gutierrez, S.; Martin, C.; Rives, V. Phys. Chem. Chem. Phys. 2004, 6, 465.

(45) Hussein, G. A. M.; Sheppard, N.; Zaki, M. I.; Fahim, R. B. J. Chem. Soc., Faraday Trans. 1991, 87, 2661.
(46) Zecchina, A.; Bordiga, S.; Spoto, G.; Scarano, D.; Spono, G.; Geobaldo, F. J. Chem. Soc., Faraday Trans. 1996, 92, 4863.

(47) Burcham, L. J.; Badlani, J.; Wachs, I. E. J. Catal. 2001, 203, 104.

(48) Dobler, J.; Pritzsche, M.; Sauer, J. J. Am. Chem. Soc. 2005, 127, 10861.

JP8078056 